\title{
Client Satisfaction with Family Planning Services and Associated Factors in the Rural Public Health Centers of Kucha District, Southern Ethiopia
}

\author{
Admasu Dulla ${ }^{*}$, Mekdes Kondale and Gemechu Kejela \\ Department of Public Health, College of Medicine and Health Science, Arba Minch University, Arba Minch, Ethiopia
}

\begin{abstract}
Background: Client satisfaction is considered as one of the factors that influence the use of family planning and other reproductive health services. It is very important to improve utilization of the service. Despite this importance, satisfaction still has been ignored by health care managers.

Objective: The main aim of this study was to assess the level of client satisfaction with family planning service in public health centers and identify factors associated with client satisfaction in Kucha district, Gamo Gofa Zone, South Ethiopia.

Methods: Facility based cross -sectional study was conducted from July 1-21, 2017 with 538 family planning service users. Respondents were selected by using systematic random sampling from four randomly selected rural health centers in the district. Data was collected by using pre-tested structured questionnaire and analyzed by SPSS version 20.0. Four diploma nurses collected the data and two B.Sc nurses supervised the data collection process. Logistic regression analyses were conducted and statistically significant association was declared at $\mathrm{P}$ value $<0.05$.

Result: About $68.4 \%$ of the clients were satisfied with the service they received. Multivariable logistic regression analysis indicated that respondents with age 35 and above years [AOR $(95 \% \mathrm{CI})=3.006(1.308,6.911)]$, respondents who attended secondary cycle $(5-8)$ [AOR $(95 \% \mathrm{CI})=2.716(1.377,7.817)]$, those for whom privacy was ensured [AOR $(95 \% \mathrm{CI})=1.771(0.738,4.252)]$, clients who received respect and friendly approach from other clinic staffs [AOR $(95 \% \mathrm{CI})=6.871(3.344,14.116)]$, those who reported convenient clinic opening hour $[\mathrm{AOR}(95 \% \mathrm{CI})=6.288$ $(2.865,13.801)]$ and those who got adequate information $[$ AOR $(95 \% \mathrm{CI})=5.043(2.362,10.767)]$ shows significant association with the outcome variable.

Conclusions and recommendations: In this study, client satisfaction is slightly high. Predictors of clients' satisfaction with family planning service in this study were age, educational level, adequacy of information to clients, convenience of clinic opening hours, respect and friendly approaches from other clinical staffs and maintenance of privacy. Appropriate Information, education and communication is needed to solve the problem.

Keywords: Family planning; Satisfaction; Kuch district; Clients
\end{abstract}

\section{ABBREVIATIONS: \\ AOR: Adjusted Odd Ratio; CI: Confidence Interval; COR: Crude Odds Ratio; CPR: Contraceptive Prevalence Rate; EDHS: Ethiopian Demographic and Health Survey; FP: Family Planning; HCs: Health Centers; ICPD: International Conference on Population and Development; MMR: Maternal}

Mortality Ratio; $\mathrm{MOH}$ : Ministry of Health; NGO: None Governmental Organization; OR: Odds Ratio; SPSS: Statistical Package for Social Science; TFR: Total Fertility Rates; USAID: United States Agency for International Development *Correspondence to: Admasu Dulla, Department of Public Health, College of Medicine and Health Science, Arba Minch University, Arba Minch,
Ethiopia, E-mail: admasudwada@gmail.com

Received date: November 14, 2018; Accepted date: December 27, 2018; Published date: January 02, 2019

Citation: Dulla A, Kondale M, Kejela G. Client satisfaction with family planning services and associated factors in the rural public health centers of kucha district, Southern Ethiopia. Clinics Mother Child Health. 2019;16:312.

Copyright: (C) 2019 Dulla A, et al. This is an open-access article distributed under the terms of the Creative Commons Attribution License, which permits unrestricted use, distribution, and reproduction in any medium, provided the original author and source are credited. 


\section{INTRODUCTION}

Family planning is crucial to improve health, human rights, and slowing population growth [1]. Family planning plays an essential role in improving maternal health, which is one of the 169 targets of Sustainable Development Goals (SDGs) world leaders have pledged to achieve by 2030. Reducing the global maternal mortality ratio to less than 70 per 100,000 live births and ensuring universal access to sexual and reproductive healthcare services, including family planning is one of 169 targets in SDGs [2].

To improve uptake of family planning, assessing client/user satisfaction level is very important. Satisfaction has often been defined using theoretical models of user satisfaction [3] but there is consensus that, it is a multidimensional concept, influenced by a variety of factors [4,5]. It can be described as a subjective concept that is assessed differently by different people [6]. A simple and practical definition of satisfaction would be the degree to which desired goals have been achieved [7].

Understanding client satisfaction with services is important, in this regard, as perceived quality is a key factor affecting service utilization [8]. Users, who satisfied with the care they received from health center, are more likely to visit it again, thereby increasing demand for the service [9]. Thus, its assessment is an important input to improving the quality of health system and also provides an opportunity for monitoring and evaluation from a consumer perspective which provides feedback for health care providers and policy makers [10].

Client satisfaction is considered as one of the factors that influence the use of family planning and other reproductive health services, despite this importance, assessment of client satisfaction still have been ignored by health care managers, which contradicted with suggestions of the emerging health care literatures towards client's views for success of service utilization [5,11]. In addition, there is no study conducted on client satisfaction towards family planning in the study area.
So, the main aim of this study is to assess status of client satisfaction and associated factors among family planning users in Kucha district, Gamo Gofa zone, in southern nations, nationalities and peoples region of Ethiopia. The findings of this study helps policy makers, healthcare managers, and service providers to implement programs in a client centered manner without compromising technical aspect of care.

\section{MATERIALS AND METHOD}

Facility based cross-sectional study was conducted among family planning users in Kucha district governmental health centers of Gamo Gofa zone from July 1-21/2017. Kuch district is one of the 15 rural woreda in Gamo-Gofa Zone, which is located at 440 $\mathrm{km}$ south of Addis Ababa (the capital city of the country).

All female family planning clients who visited rural public health centers in kucha district were the source population, and all female family planning clients who visited selected health facilities for family planning service during the study period were the study population for the study.

\section{Sample size determination and sampling procedures}

Sample size was calculated for prevalence and factors associated with the client satisfaction with family planning service and the largest sample size was used as the overall sample size of the study. Accordingly, for prevalence, sample size was determined by using single population proportion formula, considering the following assumptions: proportion of mothers satisfied on FP service as $75.3 \%(\mathrm{P}=0.753)$ from study conducted in Hosanna [16], margin of error $5 \%(\mathrm{~d}=0.05), 95 \%$ confidence level ( $\mathrm{Z}$ a $2=1.96$ and $10 \%$ contingency for non-response rate, the calculated sample size was 315 .

For factors associated with client satisfaction to family planning services, sample size was calculated by using Epi-info software as follows.

Table 1: Sample size determination using relevant determinant factors with client satisfaction on FP service.

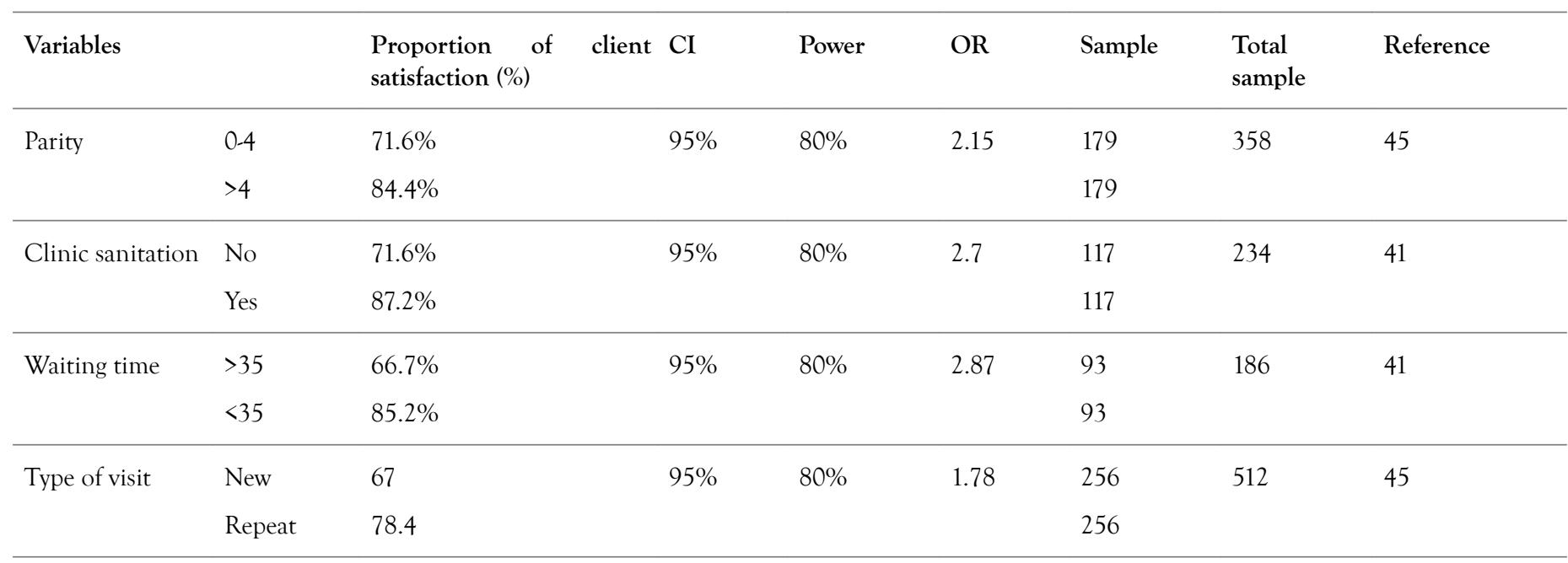

By considering 5\% non-response rate then the sample size becomes $376,246,195$ and 564 respectively for the $1^{\text {st }}, 2^{\text {nd }}, 3^{\text {rd }}$ and $4^{\text {th }}$, factors. The maximum sample size which is, 538 was taken as the final sample size for the study. 
To select the study respondents, there were six rural public health centers in the Woreda and from these four health centers were selected randomly by lottery method. Then, proportional allocation based on average client load for each facility one month preceding data collection from monthly report and FP service tally sheet was done, finally, the women included in the study were selected by using systematic random sampling method. The first client was selected by lottery method among any number from 1 to $\mathrm{k}$, and then selection continued at every $\mathrm{K}$ interval till the required sample size was obtained.

\section{Measurements}

Cut off point for client satisfaction was determined as follows: since each item had 5 point Likert Scale which ranges between 1 and 5; the scores for each dimension were calculated by summing the answers to all items in each domain: interpersonal skill (4-25), technical quality (4-20), physical env't (2-10), organization of health care (accessibility/convenience) (5-25) and clients' overall and component wise satisfaction was classified into two categories satisfied and dissatisfied by using cut of point calculated using the demarcation threshold formula: $\{($ total highest score-total lowest score) $/ 2\}+$ total lowest score. Client satisfaction level is the overall level of client satisfaction. Clients were considered as satisfied if the score is more than or equals to 58 and dissatisfied if less than 58 obtained from the demarcation threshold formula as indicated above.

\section{Data collection instruments and procedures}

Questionnaires with three different sections were prepared for client exit interview, observation during provider-client interaction and facility audit (additional for exit interview and observation) by trained nurses. Observation check lists were used to assess the process components of care which included both technical quality of care and interpersonal relationship between provider and client. Clients who were observed when receiving family planning services were asked to participate in an exit interview.

The exit interview was aimed to collect information on clients' socio-demographic characteristics, facility related factors and client satisfaction with the services provided with different components of family planning service. Client satisfaction questionnaires presented by using a 5-likert scale (1-very dissatisfied, 2-dissatisfied, 3-neutral, 4-satisfied, and 5-very satisfied). A facility inventory check lists was used to collect information on the infrastructure elements, availability of methods and equipment at facilities. Two BSc nurse supervisors and four female diploma nurses who were fluent in Amharic and not working in the study sites were recruited for data collection.

\section{Data quality control}

The questionnaire was prepared in English and translated to Amharic language then retranslated to English by another person who is blind to the original questionnaire to check its consistency. Three days (two days theoretical and one day practical) training was given before the actual data collection.
The questionnaire was pre-tested on $5 \%$ of sample in randomly selected FP clients' at health center out of the study site to ensure that the questionnaire was clear for the respondents and then necessary modification was made based on the gap identified during pre-test. The questionnaire was checked for completeness and consistency by the principal investigator at the end of each day of data collection.

\section{Data processing and analysis}

Coded data was entered and analyzed by using statistical package for social science (SPSS) version 20. In addition to descriptive statistics, both Bivariate and multivariable logistic regression analysis were performed. Descriptive analyses were done by using frequency and percentages.

Variables with P-value of less than 0.25 at binary logistic regression were entered in to multivariable logistic regression models for controlling confounding factors. Adjusted odds ratio was used to determine the strength of association between many independent variables with outcome variable after controlling confounding factors. Variables with P-value of less than 0.05 at multivariable logistic regression were taken as statistically significant predictors of the outcome variable.

\section{Ethical consideration}

Ethical clearance was obtained from IRB (Institutional Review board) of AMU, College of Medicine and Health Sciences. A formal letter of permission from AMU, department of public health, was submitted to Kucha Woreda health Office to obtain their co-operation. Permission and support letter from the Local Government was sought before the study was carried out to get recognition and collaboration. Informed written consent was obtained from all respondents before interview.

\section{RESULTS}

\section{Socio-demographic characteristics of respondents}

The age distribution of the respondents ranged from 16 to 43 year, with mean and standard deviation of 28.33 year and 5.573 respectively. Majority 310 (57.6\%) of the respondents were within the age group of 25-34 years.

About 236 (43.9\%) of respondents had no formal education and only $86(16 \%)$ were attended high school and above. Married, house wife and Gamo ethnicity constituted 529 (98.3\%), 521 (96.8\%) and 394 (73.2\%) respectively (Table 2).

Table 2: Distributions of participants by their socio demographic characteristics in rural public health centers of Kucha Woreda, Gamo Gofa Zone, South Ethiopia, July 2017.

\begin{tabular}{llll}
\hline Variables & Category & Number & Percentage \\
\hline & $15-24$ & 129 & $24 \%$ \\
\cline { 2 - 4 } Age of respondents & $25-34$ & 310 & $57.60 \%$ \\
\cline { 2 - 4 } & $35+$ & 99 & $18.40 \%$ \\
\hline
\end{tabular}




\begin{tabular}{|c|c|c|c|}
\hline \multirow{4}{*}{ Educational status } & Illiterate & 236 & $43.90 \%$ \\
\hline & $\begin{array}{l}\text { Primary cycle } \\
(1-4)\end{array}$ & 113 & $21 \%$ \\
\hline & $\begin{array}{l}\text { Secondary cycle } \\
(5-8)\end{array}$ & 103 & $19.10 \%$ \\
\hline & $\begin{array}{l}\text { High school and } \\
\text { above }\end{array}$ & 86 & $16 \%$ \\
\hline \multirow{2}{*}{ Marital status } & Married & 529 & $98.30 \%$ \\
\hline & Others & 9 & $1.70 \%$ \\
\hline \multirow{3}{*}{ Religion } & Orthodox & 285 & $53 \%$ \\
\hline & Protestant & 244 & $45.40 \%$ \\
\hline & Others ${ }^{*}$ & 9 & $1.70 \%$ \\
\hline \multirow{4}{*}{ Ethnicity } & Gamo & 394 & $73.20 \%$ \\
\hline & Gofa & 61 & $11.30 \%$ \\
\hline & Wolaita & 46 & $8.60 \%$ \\
\hline & Others $^{* *}$ & 37 & $6.90 \%$ \\
\hline \multirow{3}{*}{ Occupational status } & House wife & 521 & $96.80 \%$ \\
\hline & $\begin{array}{l}\text { Government } \\
\text { employee }\end{array}$ & 8 & $1.50 \%$ \\
\hline & Others ${ }^{* * *}$ & 9 & $1.60 \%$ \\
\hline $\begin{array}{l}\text { Keys: } \quad{ }^{*}=\text { Muslims, } \\
* * *= \\
=\text { merchants, daily } 1\end{array}$ & $\begin{array}{l}\text { wakefata, } \\
\text { borers }\end{array}$ & romo, & Gurage, \\
\hline
\end{tabular}

\section{Facility related (convenience of service) and client experience}

Concerning facility and client experience related variables, 54 (10\%) were new and the rest $484(90 \%)$ were continuing clients. Of 538 clients, 428 (79.6\%), 62 (11.5\%), 37 (6.9\%) and 11 (2\%) were inject able, implant, IUCD and pills users respectively. Majority 504 (93.7\%) were used method by their choice. Majority 377 (70.1\%) of respondents had access to the FP clinic within 30 minutes from their residence, 387 (53.3\%) reported as they waited before getting service for less than 30 minute. Majority $480(89.2 \%)$ reported health facility cleanness is good. About 477 (88.7\%) and $462(86 \%)$ of the respondents were reported as clinic working days and hours are convenient respectively.

\section{Level of client satisfaction}

Level of satisfaction of clients to different components of family planning service: Regarding specific levels of mother's satisfaction on family planning, the great majority of the client's $478(88.8 \%)$ were satisfied $50(9.3 \%)$ were very satisfied, 5
$(0.9 \%)$ were neutral and the rest $5(0.9 \%)$ were dissatisfied with comfortable and adequacy of waiting place (Table 3 ).

Table 3: Distributions of participants by their level of Satisfaction with different components of family planning serve of Kucha Woreda, 2016 $(n=538)$.

\begin{tabular}{|c|c|c|c|c|c|}
\hline Variables & $\begin{array}{l}\text { Very } \\
\text { dissatisfied }\end{array}$ & $\begin{array}{l}\text { Dissatisfi } \\
\text { ed }\end{array}$ & Neutral & Satisfied & $\begin{array}{l}\text { Very } \\
\text { satisfied }\end{array}$ \\
\hline $\begin{array}{l}\text { Respect } \\
\text { from } \\
\text { provider }\end{array}$ & $1(0.2 \%)$ & $15(2.8 \%)$ & $27(5 \%)$ & $\begin{array}{l}432 \\
(80.3 \%)\end{array}$ & $\begin{array}{l}63 \\
(11.7 \%)\end{array}$ \\
\hline $\begin{array}{l}\text { Respect } \\
\text { from other } \\
\text { staff }\end{array}$ & $0(0 \%)$ & $\begin{array}{l}68 \\
(12.6 \%)\end{array}$ & $\begin{array}{l}29 \\
(5.4 \%)\end{array}$ & $\begin{array}{l}402 \\
(74.7 \%)\end{array}$ & $\begin{array}{l}39 \\
(7.2 \%)\end{array}$ \\
\hline $\begin{array}{l}\text { Adequacy } \\
\text { of } \\
\text { informatio } \\
n\end{array}$ & $2(0.4 \%)$ & $17(3.2 \%)$ & $\begin{array}{l}28 \\
(5.2 \%)\end{array}$ & $\begin{array}{l}434 \\
(80.4 \%)\end{array}$ & $\begin{array}{l}57 \\
(10.4 \%)\end{array}$ \\
\hline $\begin{array}{l}\text { Privacy } \\
\text { maintaine } \\
\text { d }\end{array}$ & $0(0 \%)$ & 42 (7.8\%) & $\begin{array}{l}58 \\
(10.8 \%)\end{array}$ & $\begin{array}{l}382 \\
(71 \%)\end{array}$ & $\begin{array}{l}56 \\
(10.4 \%)\end{array}$ \\
\hline $\begin{array}{l}\text { Provider } \\
\text { competenc } \\
\text { y }\end{array}$ & $0(0 \%)$ & $12(2.2 \%)$ & $\begin{array}{l}23 \\
(4.3 \%)\end{array}$ & $\begin{array}{l}424 \\
(78.8 \%)\end{array}$ & $\begin{array}{l}79 \\
(14.7 \%)\end{array}$ \\
\hline $\begin{array}{l}\text { Consultati } \\
\text { on } \\
\text { duration }\end{array}$ & $2(0.4 \%)$ & $29(5.4 \%)$ & $\begin{array}{l}68 \\
(12.6 \%)\end{array}$ & $\begin{array}{l}391 \\
(72.7 \%)\end{array}$ & $\begin{array}{l}48 \\
(8.9 \%)\end{array}$ \\
\hline $\begin{array}{l}\text { Confidenti } \\
\text { ality } \\
\text { maintaine } \\
\text { d }\end{array}$ & $0(0 \%)$ & $14(2.6 \%)$ & $\begin{array}{l}30 \\
(5.6 \%)\end{array}$ & $\begin{array}{l}424 \\
(78.8 \%)\end{array}$ & $\begin{array}{l}70 \\
(13 \%)\end{array}$ \\
\hline $\begin{array}{l}\text { Convenien } \\
\text { ce of clinic } \\
\text { working } \\
\text { days }\end{array}$ & $0(0 \%)$ & $51(9.5 \%)$ & $\begin{array}{l}19 \\
(3.5 \%)\end{array}$ & $\begin{array}{l}402 \\
(74.7 \%)\end{array}$ & $\begin{array}{l}66 \\
(12.3 \%)\end{array}$ \\
\hline $\begin{array}{l}\text { Availability } \\
\text { of FP } \\
\text { methods }\end{array}$ & $1(0.2 \%)$ & $32(5.9 \%)$ & $\begin{array}{l}53 \\
(9.9 \%)\end{array}$ & $\begin{array}{l}423 \\
(78.6 \%)\end{array}$ & $\begin{array}{l}29 \\
(5.4 \%)\end{array}$ \\
\hline $\begin{array}{l}\text { Waiting } \\
\text { time }\end{array}$ & $3(0.6 \%)$ & $\begin{array}{l}72 \\
(13.4 \%)\end{array}$ & $\begin{array}{l}49 \\
(9.1 \%)\end{array}$ & $\begin{array}{l}373 \\
(69.3 \%)\end{array}$ & $\begin{array}{l}41 \\
(7.6 \%)\end{array}$ \\
\hline $\begin{array}{l}\text { Distance } \\
\text { of facility } \\
\text { site to get }\end{array}$ & $0(0 \%)$ & $\begin{array}{l}57 \\
(10.6 \%)\end{array}$ & $\begin{array}{l}24 \\
(4.5 \%)\end{array}$ & $\begin{array}{l}404 \\
(75.1 \%)\end{array}$ & $\begin{array}{l}53 \\
(9.9 \%)\end{array}$ \\
\hline $\begin{array}{l}\text { Facility } \\
\text { cleanness }\end{array}$ & $2(0.4 \%)$ & $34(6.3 \%)$ & $\begin{array}{l}25 \\
(4.6 \%)\end{array}$ & $\begin{array}{l}454 \\
(84.4 \%)\end{array}$ & $\begin{array}{l}23 \\
(4.3 \%)\end{array}$ \\
\hline $\begin{array}{l}\text { Hours of } \\
\text { service }\end{array}$ & $0(0 \%)$ & $25(4.6 \%)$ & $23(4.3)$ & $\begin{array}{l}428 \\
(79.6 \%)\end{array}$ & $62(11.5)$ \\
\hline
\end{tabular}

Client's satisfaction level by four dimensions of family planning service: The result regarding respondents' satisfaction 
on the four dimensions (components) of family planning service (accessibility, the interpersonal skill, facilities physical environment and technical quality of provider) revealed that, clients were most satisfied with the technical quality and facility physical environment while relatively less satisfied with accessibility of service and interpersonal relationship (Figure 1).

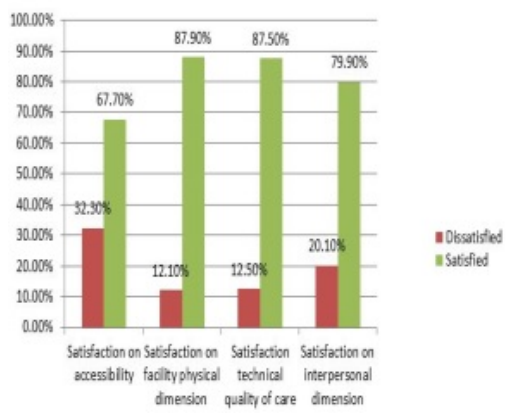

Figure 1: Client distribution of client satisfaction by four dimension of family planning service.

Overall client satisfaction level: Overall, about two third of the respondents $368(68.4 \%)$ were satisfied with the family planning service received (Figure 2).

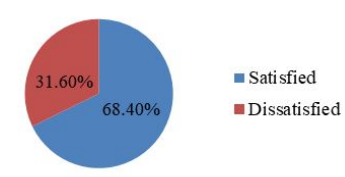

Figure 2: Percentage distribution of respondents by their overall level of satisfaction in Kucha Woreda, Gamo Gofa Zone, July 2017.

\section{Provider-client interaction observation}

A total of 538 clients had visited the service delivery points and observation was done while all of them were interacting with their providers. Regarding provider related factors, majority 477 $(88.7 \%)$ of respondents had received adequate information as they wanted and the great majority of the sampled women 457 $(84.9 \%)$ had received respect and friendly approach from clinic staffs (Table 4).

Table 4: Distributions of participants by their provider (inter-personal and technical) related characteristics in Kucha Woreda, Gamo Gofa Zone, South Ethiopia, July 2017.

\begin{tabular}{llll}
\hline Variables & Category & $\begin{array}{l}\text { Numbe } \\
\mathbf{r}\end{array}$ & Percent \\
\hline $\begin{array}{l}\text { Client concerns noted (Whether } \\
\text { provider asked client about concern }\end{array}$ & 482 & $89.6 \%$ \\
$\begin{array}{l}\text { with methods or with currently used } \\
\text { method) }\end{array}$ & 56 & $10.4 \%$ \\
\hline $\begin{array}{l}\text { Chance given to choose the method } \\
\text { they want }\end{array}$ & No & 505 & $93.9 \%$ \\
\cline { 2 - 4 } & No & 33 & $6.1 \%$ \\
\hline $\begin{array}{l}\text { Provider took blood pressure, and } \\
\text { weight during the physical exam }\end{array}$ & 536 & $99.6 \%$ \\
\cline { 2 - 4 } & No & 2 & $0.4 \%$ \\
\hline
\end{tabular}

\begin{tabular}{|c|c|c|c|}
\hline \multirow{2}{*}{$\begin{array}{l}\text { Provider asked the client about their } \\
\text { reproductive history }\end{array}$} & Yes & 156 & $29 . \%$ \\
\hline & No & 382 & $71 \%$ \\
\hline \multirow{2}{*}{$\begin{array}{l}\text { Method used explain (Whether } \\
\text { provider explained to the client how } \\
\text { to use the method) }\end{array}$} & Yes & 514 & $95.5 \%$ \\
\hline & No & 24 & $4.5 \%$ \\
\hline \multirow{2}{*}{$\begin{array}{l}\text { Visual and auditory privacy during } \\
\text { consultation and examination }\end{array}$} & Yes & 431 & $80.1 \%$ \\
\hline & No & 107 & $19.9 \%$ \\
\hline \multirow{2}{*}{$\begin{array}{l}\text { Respect and friendly approach shown } \\
\text { by the providers }\end{array}$} & Yes & 498 & $92.6 \%$ \\
\hline & $\mathrm{N}$ & 61 & $11.3 \%$ \\
\hline \multirow[t]{2}{*}{ Confidentiality maintained } & Yes & 494 & $91.8 \%$ \\
\hline & No & 44 & $8.2 \%$ \\
\hline
\end{tabular}

All of the health centers had IEC materials like flipchart, FP posters, anatomical models and contraceptive samples. All of the health centers had no standard FP guideline. All of the health centers had separate rooms for physical examination, adequate waiting area and working toilet.

Concerning the availability of basic materials (equipment and commodities), each health center had sterilizer/autoclave, blood pressure apparatus, weight scale, speculum, scissors, antiseptic solutions, disposable gloves, examination table and chair, needle, syringe and different contraceptive methods. Blood pressure apparatus, examination bed and stethoscope were shared commonly with other departments like ANC. There is no Flash light and no hand washing water in FP room in all health centers.

\section{Factors associated with mothers' satisfaction with family planning service}

Binary Logistic regression analysis: In binary logistic regression, educational status and maternal age were associated with client satisfaction whereas concerning facility related variables showed, cleanness [COR=9.831; 95\% CI: $(5.132,18.830)$ ], convenient opening hour of facility [COR=9.265; 95\% CI: $(5.288,16.235)]$, convenient clinic working days $[\mathrm{COR}=6.072 ; 95 \% \mathrm{CI}$ : $(3.380,10.749)]$ and short waiting time $[\mathrm{COR}=1.846 ; 95 \% \mathrm{CI}$ : $(1.278,2.667)]$ were significantly associated with client satisfaction.

Regarding providers related variables, maintaining privacy during physical examination $[\mathrm{COR}=8.789$; 95\% CI: $(5.460,14.150)]$, treatment with respect and friendly approach from other clinic staffs [COR=7.768; 95\% CI: $(4.582,13.169)]$, received adequate information $[\mathrm{COR}=2,513$; 95\% CI: $(1.465,4.309)]$, had received explanation about how the method used [COR=12.133; 95\% CI: $(4.078,36.096)]$, getting chance to choice the method and those whose concern noted [COR=4.824: 95\% CI: $(2.282,10.200]$ and $[\mathrm{COR}=3.324: 95 \%$ CI: $(1.889,5.847]$ were significantly associated with client satisfaction respectively. 
Multivariable logistic regression: At multivariable logistic regression, variables like age, educational status, and convenience of clinic opening hour, getting adequate information, treatment with respect and dignity and maintenance of privacy were significantly associated with client satisfaction.

Concerning respondents age, mothers who were 35 or more years old were 3 times more likely to be satisfied with the service compared to those who were $15-24$ years $[A O R=3.006 ; 95 \% \mathrm{CI}$ : $(1.308,6.911)]$. Educational status of the respondents was a significant predictor of client satisfaction, in that, respondents who attended secondary cycle education (4-8) were 3 times more likely to be satisfied than those who had no formal education [AOR=3.281; 95\%CI: $(1.377,7.817)$ ].
As to facility related factors, clients who reported that the opening hours of clinic was convenient were 6.3 times more satisfied than their counterparts [AOR $(95 \%$ CI $)=6.288$ $(2.865,13.801)]$.

Regarding provider related characteristics, clients who received adequate information about the service were 5 times more likely to be satisfied as compares to their counterpart [AOR $(95 \%$ CI $)=5.043(2.362,10.767)$. Similarly, clients that were treated with respect and dignity by other clinic staff were 7 times more likely to be satisfied when compares to their counterparts [AOR $(95 \%$ CI $)=6.871(3.344,14.116)]$. Likewise, clients for whom privacy was maintained were 4.7 times more likely to be satisfied with the service than their counterparts $[$ AOR $(95 \% \mathrm{CI})=4.706$ (2.331, 9.498) (Table 5).

Table 5: Logistic regression showing predictors of client satisfaction with family planning service among mothers visited rural health centers in Kucha District, July 2017 ( $\mathrm{n}=538)$.

\begin{tabular}{|c|c|c|c|c|c|}
\hline \multirow{2}{*}{ Variables } & \multirow{2}{*}{ Category } & \multicolumn{2}{|c|}{ Satisfaction status } & \multirow[t]{2}{*}{ COR $(95 \% \mathrm{CI})$} & \multirow{2}{*}{$\operatorname{AOR}(95 \% \mathrm{CI})$} \\
\hline & & Dissatisfied & Satisfied & & \\
\hline \multirow{4}{*}{ Educational status } & Illiterates & $\begin{array}{l}74 \\
(13.8 \%)\end{array}$ & $162(30.1 \%)$ & 1 & 1 \\
\hline & Primary & $\begin{array}{l}58 \\
(10.8 \%)\end{array}$ & $55(10.2 \%)$ & $\begin{array}{l}0.433 \\
(0.273,2.686)\end{array}$ & $0.495(0.265,1.925)$ \\
\hline & Secondary & $\begin{array}{l}12 \\
(2.2 \%)\end{array}$ & $91(16.9 \%)$ & $\begin{array}{l}3.464 \\
(1.787,6.714)\end{array}$ & $\begin{array}{l}3.281 \\
(1.377,7.817)^{*}\end{array}$ \\
\hline & $\begin{array}{l}\text { High school and } \\
\text { more }\end{array}$ & $\begin{array}{l}26 \\
(4.8 \%)\end{array}$ & $60(11.2 \%)$ & $\begin{array}{l}1.054 \\
(0.617,1.802)\end{array}$ & $1.248(0.590,2.642)$ \\
\hline \multirow{3}{*}{ Age of client } & $15-24$ years & $\begin{array}{l}45 \\
(8.4 \%)\end{array}$ & $84(15.6 \%)$ & 1 & 1 \\
\hline & $25-34$ years & $\begin{array}{l}103 \\
(19.1 \%)\end{array}$ & 207 (38.5\%) & $0.533(0.294,0.968)$ & $1.324(0.707,2.480)$ \\
\hline & 35 and more & $22(4.1 \%)$ & 77 (14.3\%) & $0.574(0.338,0.975)$ & $3.006(1.308,6.911)^{*}$ \\
\hline \multirow{2}{*}{$\begin{array}{l}\text { Convenience of clinic } \\
\text { hours }\end{array}$} & Yes & $113(21.0 \%)$ & 349 (64.9\%) & $9.265(5.288,16.235)$ & $6.288(2.865,13.801)^{*}$ \\
\hline & No & $57(10.6 \%)$ & $19(3.5 \%)$ & 1 & 1 \\
\hline \multirow{2}{*}{$\begin{array}{l}\text { Convenience of clinic } \\
\text { working days }\end{array}$} & Yes & $128(23.8 \%)$ & 349 (64.9\%) & $6.027(3.380,10.749)$ & $2.147(0.893,5.166)$ \\
\hline & No & $42(7.8 \%)$ & $19(3.5 \%)$ & 1 & 1 \\
\hline \multirow{2}{*}{ Respect from provider } & Yes & $144(26.8 \%)$ & 354 (65.8\%) & $4.565(2.318,8.994)$ & $1.771(0.738,4.252)$ \\
\hline & No & $26(4.8 \%)$ & $14(2.6 \%)$ & 1 & 1 \\
\hline \multirow{2}{*}{ Privacy } & Yes & 94 (17.5\%) & $337(62.6 \%)$ & $8.789(5.460,14.150)$ & $4.706(2.331,9.498)^{*}$ \\
\hline & No & $76(14.1 \%)$ & $31(5.8 \%)$ & 1 & 1 \\
\hline Facility cleanness & Yes & $125(23.2 \%)$ & 355 (66.0\%) & $9.831(5.132,18.830)$ & $2.155(0.835,5.566)$ \\
\hline
\end{tabular}




\begin{tabular}{|c|c|c|c|c|c|}
\hline & No & 45 (8.4\%) & $13(2.4 \%)$ & 1 & 1 \\
\hline \multirow{2}{*}{ Respect from staff } & Yes & $112(20.8 \%)$ & $345(64.1 \%)$ & $7.768(4.582,13.169)$ & $6.871(3.344,14.116)^{*}$ \\
\hline & No & $58(10.8 \%)$ & $23(4.3 \%)$ & 1 & 1 \\
\hline \multirow[t]{2}{*}{ Client concern noted } & Yes & $138(25.7 \%)$ & $344(63.9 \%)$ & $3.324(1.889,5.847)$ & $1.493(0.616,3.618)$ \\
\hline & No & $32(5.9 \%)$ & $24(4.5 \%)$ & 1 & 1 \\
\hline \multirow{2}{*}{ Method used explain } & Yes & $150(27.9 \%)$ & $364(67.7 \%)$ & $12.133(4.078,36.096)$ & $1.168(0.220,6.203)$ \\
\hline & No & $20(3.7 \%)$ & $4(0.7 \%)$ & 1 & 1 \\
\hline \multirow{2}{*}{$\begin{array}{l}\text { Chance given for } \\
\text { choice }\end{array}$} & Yes & $148(27.5 \%)$ & $357(66.4 \%)$ & $4.824(2.282,10.200)$ & $0.445(0.083,2.393)$ \\
\hline & No & $22(4.1 \%)$ & $11(2.0 \%)$ & 1 & 1 \\
\hline \multirow{2}{*}{ Information adequacy } & Yes & $139(25.8 \%)$ & $338(62.8 \%)$ & $2.513(1.465,4.309)$ & $5.043(2.362,10.767)^{*}$ \\
\hline & No & $31(5.8 \%)$ & $30(5.6 \%)$ & 1 & 1 \\
\hline \multirow[t]{2}{*}{ Waiting time } & $<30 \mathrm{~min}$ & $73(13.6 \%)$ & $214(39.8 \%)$ & $1.846(1.278,2.667)$ & $1.420(0.850,2.372)$ \\
\hline & $\geq 30 \mathrm{~min}$ & 97 (18.0\%) & $154(28.6 \% 0)$ & 1 & 1 \\
\hline \multirow{2}{*}{ Confidentiality } & Yes & $145(27.0 \%)$ & 349 (64.9\%) & $3.167(1.691,5.930)$ & $2.881(0.877,9.463)$ \\
\hline & No & $25(4.6 \%)$ & $19(3.5 \%)$ & 1 & 1 \\
\hline
\end{tabular}

${ }^{*}=$ Variables showing significant association at P-value $<0.05$

\section{DISCUSSION}

The overall proportion of mothers who were satisfied with family planning service in this study was $68.4 \%$. This study finding is similar with the study conducted in Bangladesh which reported $67 \%$ of client satisfaction level [10]. But it is low when compared to other study conducted in Northern Nigeria (85\%) [14], study conducted in primary health care in south west Ethiopia (80.9\%) [15] and Hosanna (75.3\%) [16]. The difference might be attributed to the fact that this study was conducted in primary health care level in rural area where as that of hosanna and Northern Nigeria was conducted in urban health facilities where there are relatively adequate number of competent health professionals and supplies. And also could be attributed to socio cultural, health service quality, study period difference due to the increase in expectation of clients to the service they are going to receive with rapid advancement in technology and peoples thinking.

However, the finding of this study was much higher than what has been observed in the study conducted in Pakistan (33\%) [17], Ghana, Tanzania and Kenya which reported as $59.2 \%$, $46.9 \%$ and $46 \%$ satisfaction level respectively [18]. The likely explanations for this dissimilarity might be because of a real difference in quality of services provided, expectation of mothers or the type of health facilities, socio-cultural and study period differences.
This study further revealed the predictors of clients' satisfaction with family planning service. Accordingly, age, educational status, respect from other clinic staffs, maintaining privacy, adequacy of information given by service providers and clinic opening hour were significant predictors of the outcome variable.

Client's age was significantly associated with client satisfaction in family planning services. This is consistent with studies conducted in Jimma [19]. But the effect of age contradicted with the study finding in Kenya which reported younger clients were more likely to be satisfied as compares to older clients [12].

Educational status of the respondents was found to be significantly associated with their level of satisfaction with family planning service. This finding is similar with studies conducted in Ghana and Ethiopia [15,20]. This finding is also consistent with previous studies conducted in Senegal, Kenya and South west Ethiopia [12,19,21]. But it is not supported by the study conducted in Hosanna where educational level of respondents was not associated with client satisfaction. The possible explanation of this variation may be because this study was conducted at rural area whereas that of Hosanna was in urban area, so people in whatever level of education may have similar expectation with the care that they will get in urban area.

In this study, the way clients were received by clinic staffs, were found to be associated with client satisfaction. This is similar with the study conducted in Southeastern Nigeria, which 
reported clients who treated with respect were more satisfied than their counterparts [22]. This is also comparable with what has been reported from study conducted in Northern Nigeria that showed clients who were treated with respect and dignity by both service providers and other clinic staff were 6 and 2 times more likely to be satisfied respectively [14].

In this study, adequacy of information provided was found to be the key factors influencing satisfaction. Mothers who received adequate information were more satisfied when compares to those who didn't received sufficient information. This agrees with the studies conducted in Hosanna and southeast Nigeria $[16,22]$. This is also comparable with what has been reported from study conducted in Northern Nigeria that showed clients that were treated with respect and dignity by other clinic staff were 2 times more likely to be satisfied [14].

In this study, mothers for whom privacy was maintained were 4.7 times more likely to be satisfied with the service they received. This agrees with the study conducted in Southern Nigeria, which reported that maintaining privacy was significantly associated with level of client satisfactions [22]. But it contradicts with the study conducted in Northern Nigeria which reported there was no association between privacy and client satisfaction [14]. The possible explanation of this finding might be because this study was conducted at rural area, so, people in rural communities might have different expectation with the privacy that they will get.

The results from this study indicated that, clinic opening hours are significantly associated with client's satisfaction in family planning service. This is similar with study conducted in Hosanna which showed mothers who reported convenient clinic opening hour were 4.7 times more likely satisfied than those reported as not convenient [16]. In contrast, report from study conducted in Northern Nigeria showed, there was no observed association between hours with family planning client satisfaction [14]. This discrepancy observed in this study might be attributed to study set up and socio cultural difference.

\section{STRENGTH OF THE STUDY}

To minimize courtesy bias, interviews were conducted in an area with adequate privacy and without any involvement of health care providers. The study includes provider-client interaction observation and facility inventory assessment not solely based on client information.

\section{LIMITATION OF THE STUDY}

Courtesy bias (this method receives subjective responses). Respondents usually would not want to express negative opinion to strangers on their level of satisfaction, and this could have resulted to overestimation of reported level of satisfaction with FP services. Since it is cross sectional study, it is difficult to establish causal relationship.

\section{CONCLUSION}

This study shows that, slightly high numbers of clients were satisfied with the FP service. Out of the four dimensions assessed, clients were satisfied with the technical quality of care, facility physical dimension and interpersonal aspect while less satisfied with accessibility of service in this study. The predictors of clients' satisfaction with FP service indicated in this study were age, educational level, and information, convenient of clinic opening hours, respect and friendly approaches from clinical staffs and maintaining privacy.

\section{RECOMMENDATION}

Those factors associated with client satisfaction with FP service identified in this study should be used to shape future provision of family planning services. Thus the responsible authorities (Gamo Gofa Zone health department, Kucha Woreda health office, NGO working on this area, policy makers and other interested bodies) have to work on this issue to enhance the client satisfaction and to develop a system to control factors associated with client satisfaction.

Further studies are recommended in terms of mixed (qualitative and quantitative) data collection method as it is important for client satisfaction and incorporate healthcare workers' attitude into the factors determining client satisfaction.

\section{ETHICAL APPROVAL AND CONSENT TO PARTICIPATE}

Ethical clearance was obtained from Arba Minch University Research Ethic review committee to conduct the study. In addition permission was obtained from Gamo Gofa zone health Department, Kucha district manager, managers of health centers. Confidentiality was secured by informing and giving awareness to the data collectors not to record identifiers of the client and disseminate any information obtained from client.

\section{Availability of Data and Materials}

All data and materials are available and will be submitted by the author if needed.

\section{Conflict of Interest}

The authors declare that they have no conflict of interest regarding the publication of the paper.

\section{Funding}

The study was funded by Arba Minch University.

\section{Authors' Contribution}

All authors wrote the proposal, participated in data collection, analyzed the data and drafted the paper, approved the proposal with great revisions and revised subsequent drafts of the paper. In addition, all authors contributed in the designing of the methodology, write-up and read and approved the final manuscript. 


\section{ACKNOWLEDGEMENT}

Authors would like to thank Arba Minch University, College of medicine and health sciences for initiating them to conduct this study and financial support. Deep appreciations have gone to manager of Kucha district and managers of the health centers. Also, special thanks to data collectors, supervisors and all peoples who involved in the study directly or indirectly.

\section{REFERENCES}

1. Speidel JJ, Thompson KMJ, Harper CC. Family Planning: Much Progress But Still Far To Go. Solutions. 2014;4: 54-61.

2. Barclay H, IPPF. Sustainable Development Goals: A SRHR CSO guide for national implementation . 2015;1-17.

3. Donabedian A. An Introduction to Quality Assurance in Health Care. Oxford University Press, USA.

4. Christiaens W, Bracke Assessment of social psychological determinants of satisfaction with childbirth in a cross-national perspective. BMC Preg Childbirth. 2017;7: 26.

5. Williams T, Schutt-Aine J, Cuca Y Measuring family planning service quality through client satisfaction exit interviews. Int Fam Plan Perspect. 2000; 26: 63-71.

6. Locker D, Dunt D . Theoretical and methodological issues in sociological studies of consumer satisfaction with medical care. SocSci Med. 1978;12: 283-292.

7. Donabedian A Explorations in quality assessment and monitoring. Ann Arbor (Michigan): Health Administration Press 3-28 1980.

8. Dettrick Z, Firth S, Soto EJ. Do strategies to improve quality of maternal and child health care in lower and middle income countries lead to improved outcomes? A review of the evidence. Plos One 2018;8: e83070.

9. Andaleeb SS Service quality perceptions and patient satisfaction: a study of hospitals in a developing country. Soc Sci Med 52: 1359_ 1370.

10. Derose KP, Hays RD, McCaffrey DF, Baker DW. Does physician gender affect satisfaction of men and women visiting the emergency department? J Gen Intern Med 2001;16: 218226.

11. Donabedian A. The Lichfield lecture. Quality assurance in health care: Consumers' role. Qual Health Care. 1992; 1: 247251.
12. Agha S, Do M . The quality of family planning services and client satisfaction in the public and private sectors in Kenya. Int J Qual Health Care(2009); 21: 8796.

13. Bazant ES, Koenig MA "Women's satisfaction with delivery care in Nairobi's informal settlements," Inter J Qual Health Care (2009); 21: 79-86.

14. Kaoje UA, Sambo MN, Oche MO, Saad A, Raji MO, Determinants of client satisfaction with family planning services in government health facilities in Sokoto, Northern Nigeria. Sahel Med J(2015); 18: 20-26.

15. Tafese F, Woldie M, Megerssa B Quality of family planning services in primary health centers of Jimma zone, southwest (2013); Ethiopia. Ethiop J Health Sci 23: 245-254.

16. Argago TG, Hajito KW, Kitila SB Client's satisfaction with family planning services and associated factors among family planning users in Hossana Town Public Health Facilities, South Ethiopia: Facility-based cross-sectional study. Int J Nurs Pract (2015);7: 7483.

17. Rehman F, Janjua R, Shahzad H Client Satisfaction Regarding Family Planning Services in Reproductive Center at Jinnah Hospital, Lahore: PJMHS (2015); 9: 1048-1050.

18. Nikiéma B1, Beninguisse G, Haggerty JL Providing information on pregnancy complications during antenatal visits: unmet educational needs in sub-Saharan Africa. Health Policy and Plan (2009) ; 24: 367-376.

19. Assefa F, Mosse A, H Michael Y Assessment of clients' satisfaction with health service deliveries at Jimma university special hospital. Ethiop J Health Sci (2011);21: 101-109.

20. Hutchinson PL, Do M, Agha S Measuring client satisfaction and the quality of family planning services: a comparative analysis of public and private health facilities in Tanzania, Kenya and Ghana. BMC Heralth Ser Res 2011; 11: 203.

21. Assaf S, Wang W, Mallick L Quality of Care in Family Planning Services at Health Facilities in Senegal. DHS Analytical Studies No. 55. Rockville, Maryland, USA 2015.

22. Uzochukwu BS, Onwujekwe OE, Akpala CO Community satisfaction with the quality of maternal and child health services in Southeast Nigeria. East Afr Med J 2004; 81: 293-299. 